Chengping Zhang

\title{
MORAL LUCK IN THOMAS HARDY'S FICTION
}

$\mathrm{T}$

HOMAS HARDY IS NOTORIOUS for persecuting his characters mercilessly with coincidences and untimely chance and luck. I suggest that this idiosyncrasy is his exploration of the problem of "moral luck" to confront the reader with such fundamental ethical questions as how to make moral judgments and attribute moral responsibility.

Making moral judgments is an essential part in our life, and our moral thoughts and beliefs invariably find expression mainly in the form of judgments. When we make moral judgments we are applying moral concepts to ourselves and others to make sense of our lives, to provide a common ground for interpersonal moral communication and to enable our moral growth. Making such judgments is also an exercise of moral confidence: whether we are consistent about our moral belief, whether we are confident enough to voice our attitudes, and whether we are courageous enough to be responsible for our judgment. This practice has been so internalized into our psychology that it becomes almost part of us-a demonstration of our existence as moral beings.

Yet such confidence can meet serious setbacks, especially when we find that an agent cannot be totally responsible for the result of her action. For example, how should we judge Agamemnon's decision to sacrifice his daughter so that the Greek fleet can set out for war? Can we accept Seth's self-justification for cutting her daughter's throat with a handsaw or should we condemn her violent motherly love in Toni Morrison's Beloved? Would Anna Karenina's decision to elope with Vronsky have been justifiable if it had resulted in their living a happy life together? These difficult situations directly challenge our moral concepts and beliefs and force us to admit our moral uncertainty and self-conceit: do we really believe in what we declare? Are those values 
we hold dear always commensurable? Do we really think that good will is unconditionally good in any situation?

We find difficulties in such boundary situations because these agents are invariably affected by an alien and unexpected link in the chain of life: untimely chance and luck. By chance they either run into a moral dilemma or their actions turn out badly, but this cannot prevent them from being judged by us - the problem is, should we judge them by their intention and ignore the harm their actions bring? Or should we thus accuse them of being morally deficient or invalid because of something they cannot control? When we ask such questions we are also questioning the Kantian belief that an agent should be judged only by what she wills and that good or bad luck should not influence our moral assessment of her-which assumes morality is free from external contingency, and any rational agent can have full control of her will and choice and therefore should bear complete responsibility for her action. Yet we obviously feel that luck has penetrated the sanctuary of morality and leaves footprints on our moral existence as it does anywhere else in our lives.

This challenge to the traditional Kantian criterion of moral judgment was first raised by Bernard Williams and Thomas Nagel in two articles with the same title "Moral Luck" in 1976, arguing that luck does influence an agent's self-assessment (which is Williams's main concern) and people's moral judgment as well (which is Nagel's focus). According to Nagel, where "a significant aspect of what someone does depends on factors beyond his control, yet we continue to treat him in that respect as an object of moral judgment, it can be called moral luck." ${ }^{1}$ He further divides moral luck into four kinds: constitutive luck, which determines one's inclinations, capacities and temperament; circumstantial luck, which determines the kind of problems and situations one faces; antecedent luck, which determines one's choice and actions by antecedent circumstances; and resultant luck, which refers to the way one's actions and projects turn out. Each kind, though beyond the agent's control, will influence her will or choice and ultimately the result of action (Nagel, p. 28). The sanctuary turns out to have a back door through which luck slips in: if morality is not immune to luck, then moral risk is inevitable for an agent while making decisions and taking action.

Ever since then moral philosophers have been trying to prove or deny the existence of moral luck or to solve the problem it raises in our moral practice. Martha Nussbaum encourages us to see it positively as an indispensable part of the human condition which make a good and 
fruitful life. ${ }^{2}$ Nafsika Athanassoulis brings evidence to show that Kant's attitude toward luck is not absolute, that Kant distinguishes two human characters—an "intelligible" self and a "sensible" self—and admits that the "sensible" self can be influenced by empirical contingencies. That is why Kant emphasizes the importance of education, good teachers and role models. ${ }^{3}$ There are also arguments admitting that moral luck does exist yet unwilling to yield to the problems it brings. Brian Rosebury, for instance, argues that the notion of moral luck is based on a misunderstanding of terms (e.g. moral assessment/judgment, lack of control, responsibility, justification), therefore if we make clear what the key terms mean and apply them strictly, no problem would arise. ${ }^{4}$

Such arguments seem to miss the point Williams and Nagel aim at-for they are talking about our inconsistency in theory and practice, that we may hold the Kantian belief yet act differently, that the results do influence our moral assessment of the agent. Moreover, we are associating an agent's moral character with her behavior and judging not only her behavior but herself; and she must be morally responsible for the result of her action, a result which can be influenced or even determined by good or bad luck. Nagel makes this point clear enough: "We may be persuaded that these moral judgments are irrational, but they reappear involuntarily as soon as the argument is over. This is the pattern throughout the subject" (p. 33).

Is there a solution to the problem of moral luck? To redefine the term or certain key words and restrict their use is simply dodging the problem; to argue that we should be aware of human fallibility and epistemic limitation, that we should acquire more information about the particular case so as to make the best and soundest judgment we can manage, that we should modify our attitude and abandon hostility toward the agent and base our judgment only on her action instead of her whole being means moral luck will remain a problem before we change old practice. And chances are that it will remain a problem. Still it is illuminating to realize how moral luck once again calls our attention to those fundamental ethical questions-what it is to be human and to be a moral being; and to realize that the human condition contains two irreconcilable sides yet we are constantly struggling to reconcile them as best as we can.

Nicholas Rescher comments that most cases of moral luck discussed in the debate are too extreme to be of much relevance to our everyday life. Since ordinarily our moral evaluation does reflect "the ordinary course of things," we should not forsake moral appraisals which are "standardized" rules to help us make common sense judgments about 
"the situation of the ordinary common run of things." This argument is sound enough, but extreme cases do exist and may not be as uncommon as Rescher declares. To neglect extreme cases is to risk falling into complacency, narrow-mindedness, and moral rigidity.

One realm above all others which abounds in extreme cases is fictional narrative, in which we are provided a better opportunity to avoid epistemic limitation, or external contingency, or the pressure for instant response, and hence we are also allowed a better opportunity to practice (in both senses) the most reasonable, objective and humane moral judgment. This is also one important reason why we read literary narrative.

Making judgments while reading a fictional narrative, however, is quite different from our daily practice: we are facing a more complicated structure. In The Company We Keep: An Ethics of Fiction Wayne Booth differentiates three voices in a text-the narrator, the implied author and the writer-and suggests that an ethical reading of the text will disclose the relationship between the reader and the implied author. ${ }^{6}$ Based on this model we can identify at least three dimensions of moral judgment in the narrative.

The first is the characters' self-judgment and the judgment from other characters, from the community and society, which may be called "the direct judgment" because it will influence the characters' lives directly. The second dimension is the narrator's judgment on the characters, which exists throughout a fiction either diagetically through authorial comment, advice and moral admonition (as in the more conventional type of novel), or in a less straightforward way through the narrator's deliberate choice of form and style to present the plot, characters and actions. The narrator's point of view is nevertheless subjective: he narrates what he deems important and proper, and these are judgments closely related to his moral principles and views. Above the previous two types is the implied author's judgment, which is, namely, "implied." It shows the values the text is intent on conveying, and is fully clear to the reader only when she finishes reading and grasps the work as a whole.

When the three levels of moral assessment are identical, the reader will easily recognize the embedded ethical code in the story (even if she may disapprove it). In this case, the narrator can be regarded as a reliable and faithful agent of the implied author. If there lies contradiction between the direct judgment and the narrator's judgment, or if the narrator strikes the reader as unreliable, then she may remain dubious and has to undergo further exploration before pinning down the implied author's judgment and readjusts her own accordingly. 
It is interesting to note that different works written by the same author may demand that the reader make moral judgments differently-such as Thomas Hardy's novels, in which cases of moral luck abound. His frequent recourse to coincidence and accident, sometimes reproached on the ground of verisimilitude, proves especially interesting to the ethical reader. This essay will take his Far from the Madding Crowd (1874) and The Return of the Native (1878) as examples to test how cases of moral luck work differently in the two novels. ${ }^{7}$

The first case in Madding Crowd is the Valentine card Bathsheba sends to Boldwood with a seal "Marry Me" on it in Chapter XIII. This is a case of resultant luck for Bathsheba and circumstantial luck for Boldwood. When sending the card Bathsheba does not expect that it will ignite the excessive passion buried in the solemn and reserved Boldwood and later throw him into mental disorder which leads to his shooting Troy. To her it is just a "childish game of an idle minute" (FMC, p. 158), yet it develops in such an unexpected direction that she has to take serious moral responsibility for her recklessness and whimsy. As she implores Boldwood's forgiveness and accuses herself as "wanton" (p. 101), "thoughtless, inexcusable, wicked" (p. 270), she is experiencing what Bernard Williams calls "agent-regret," which is a regret toward her own past action which involves her voluntary agency however unintentionally that might be. ${ }^{8}$ This uncontrollable bad luck not only influences Bathsheba's self-judgment, but also other characters' judgment of her: as the victim of her action, Boldwood accuses her of being "heartless" (p. 159); as an onlooker, Gabriel Oak blames her with devastating candour and judges her trick as "unworthy of any thoughtful, and meek, and comely woman" (p. 105).

Meanwhile, this case is one of circumstantial luck for Boldwood. Had he not received the card from Bathsheba, he might have remained unconscious of his extreme personality; yet bad luck subjects him to this test and he obviously fails it. His obsession becomes a haunting nightmare to Bathsheba: he takes advantage of her sense of guilt, stubbornly refuses to forgive her and persistently presses her to accept him, totally disregarding her obvious unwillingness and her frank claim that she does not love him. His attempt to bribe Troy to marry Fanny and give up Bathsheba is not only ridiculous but dishonorable. Although this situational luck does not entail negative moral judgment on Boldwood by himself or other characters (except Oak), the narrator's comments clearly invite the reader both to pity him and to blame him.

The second case is Fanny's going to the wrong church for her wedding 
with Troy in Chapter XVI. This is a case of circumstantial luck for Troy. If Fanny had arrived on time they would have married no matter how unenthusiastic Troy is; then he would not be blamed for seducing and deserting Fanny, and he would not blame himself and feel deep remorse later when Fanny dies giving birth to their child. Of course if this happened the plot of the novel would have to take a different course; still it does render Troy blameworthy for his ill-treatment of Fanny.

Although moral judgment remains an urgent need in Madding Crowd, it never becomes controversial. We do not feel particularly indignant or troubled that Bathsheba, Boldwood and Troy have to assume more severe moral responsibility than they otherwise would. These cases do arouse tensions, anxiety and pathos; yet we can always rely on the narrator's guidance as well as on the moral compass of the male protagonist, the upright and trustworthy Oak. When the last page of the novel is turned, we may be glad that things end as we expected although we feel sorry for the sufferings the protagonists have undergone. We may even feel that the two cases are dramatized to accentuate the contrast between virtue and vice and to aggravate the consequence caused by moral defects.

Thus moral luck in Madding Crowd is adopted not only as a literary strategy to complicate the plot and to arouse tension and suspense, but also as a moral strategy to testify to the existence of a moral universe and the final triumph of the good and the faithful. This also assures the reader that luck cannot harm the truly virtuous agent and allows the reader enough confidence in making the right judgment.

Yet when we move into another two cases of moral luck in Return, we will find the situation more complicated. The first case is Clym's semi-blindness due to his ceaseless night reading. At first glance, this has nothing to do with moral luck although it is bad luck. It does not harm the public opinion of his morality but wins him pity and sympathy from the community instead. However, this accidental affliction does influence Eustacia's judgment on his moral integrity. In a moment of anguish Eustacia accuses him directly: "Your blunders and misfortunes may have been a sorrow to you, but they have been a wrong to me. . . . You deceived me" ( $R N$, p. 256). Her accusation is not unreasonable because the accident does leave Clym unable to justify his hasty decision to marry Eustacia.

Then we find that Clym is not only subjected to Eustacia's judgment but also to the narrator's: the narrator provides abundant evidence to prove that Clym is culpable for his decision. Clym's motive in marrying 
Eustacia, besides sexual attraction, is to make her a helpmate in his school project, yet she has explicitly expressed her lack of interest in teaching. Moreover, even when Clym is proposing to Eustacia he is clearly conscious that "she loved him rather as a visitant from a gay world to which she rightly belonged than as a man with a purpose opposed to that recent past of his which so interested her" (p. 158). He also knows that she is willing to marry him only in the belief that he will abandon his project and return to Paris, yet he chooses to keep silent about it. By exposing these traces unknown to other characters, the narrator puts Clym into the scope of moral judgment and indicates that the reader should think twice when attributing responsibility.

The second case is the "closed door" which leads to Mrs. Yeobright's lonely death on the heath and the breach of Eustacia and Clym's marriage. Certainly Eustacia is not blameless—she does not open the door immediately when Mrs. Yeobright knocks, and she fails to tell Clym about his mother's visit after he wakes up. Yet again the narrator convinces the reader that this is Eustacia's moral bad luck: there is much highly contrived antecedent luck-that the two women once quarreled because Mrs. Yeobright suspected Eustacia's relationship with Wildeve; and circumstantial luck - that Wildeve and Mrs. Yeobright choose to pay a visit on the same day; that Clym happens to fall asleep before both of them arrive; that he happens to call out "mother" in his dream so that Eustacia believes he is awakened and will open the door himself; that the heart-broken Mrs. Yeobright happens to be bitten by an adder on her weary way back. If any of these incidents did not occur, tragedy would not strike; but without inquiring an explanation Clym claims Eustacia an inhuman and treacherous murderess and even denies all the goodness in her: "How bewitched I was! How could there be any good in a woman that everybody spoke ill of" (p. 256). Not until Eustacia's death does Clym realize his limitation on making moral judgments. Thus the direct judgment is undermined by the narrator's strong diagetic and mimetic counter-argument.

Contrary to the case in Madding Crowd, Return appears to provide the reader no comfort, no security and no solution to the moral difficulties the narrative raises. The narrator's judgment remains ambiguous throughout the novel. He has to give the main characters a moral position, but he refuses to make that position fixed. This indecisiveness in effect mars the characterization: Leonard W. Deen points to the incongruities between the tragic and mythological weight the narrator loads on Eustacia and her intellectual limitation and mundane aspira- 
tions and considers Hardy's attempt as "self-defeating." Dale Kramer suggests that this flaw is due to Hardy's inexperience in appropriating the genre of tragedy into narrative form. ${ }^{10}$

Yet this incongruity can be accounted for differently, in terms of the narrator's eager participation in the moral debate to counter-balance that hasty and irrational judgment the public levels at Eustacia. He therefore spares no effort to highlight the intrinsic value she possesses-her vitality, passion, beauty, and aspiration for higher aims and self-fulfillment. These qualities are good in themselves; yet chance and luck leave them unfulfilled, dissatisfied and defeated. By granting Eustacia grandeur and nobility the narrator may succeed in winning the reader's sympathy and appreciation for Eustacia, but he fails to provide a satisfactory answer to the problem of moral judgment. When the reader realizes the narrator's shortcomings and unreliability, she has to pause and ask: how to make the right judgment?

With this consciousness the reader approaches the implied author's judgment. By revealing the limitations of both the direct judgment and the narrator's judgment, the implied author entreats the reader to hesitate before making any acceptable judgment. This "hesitation of judgment" is not an indefinite deferral or withdrawal of judgment, but a warning not to rush to judgment, when circumstances of luck may lurk around and influence the result of an agent's action, which may be beyond our knowledge. Moral luck, the initiator of "poetic justice" in Madding Crowd, transforms unexpectedly into a rebel in Return. It challenges the confidence the reader has acquired from reading Madding Crowd and reminds the reader how problematic and dangerous a hasty moral judgment can be: good will can yield suffering, whereas insensibility to moral luck and its grave influence can lead to injustice. These are life's little ironies we have to live with, and our response to them demonstrates our moral status and subjects us to moral assessment in turn.

After the moment of hesitation, we may view the characters and the novel more clearly: selfish and willful as she is, Eustacia is admirable for her dignity and perseverance; Clym is naïve and obstinate, but his love of humanity and courage in self-sacrifice is sincere and sublime. When we come to perceive the novel's complicated dimensions of moral judgment and its morally deficient characters, we are likely to feel that they deserve better. This is not an appeal to a transcendental Deity but to the reader and humanity at large-that when we face the grind of stern reality, compassion and love is all we can offer to prevent inflicting 
further pain on our fellowmen. Clym's plan to spread the Positivist ethical values to Egdon Heath and to teach his people to bear the misery of life fails; yet surprisingly enough, his goal is partly achieved by a story telling about his failure- $\mathrm{a}$ rich and artistic type of ethics.

One reason why cases of moral luck give readers different experiences in the two novels lies in the narrative strategies. Although both novels have a third-person omniscient narrator, they strike the reader as possessing very different personality and moral outlook. The narrator in Madding Crowd is easy-going, humorous, entertaining and morally confident, while the narrator in Return is somber, gloomy, dissatisfied, meditative and morally skeptical. They also take different moral stances in judging their characters: the reader will find in retrospect that Bathsheba and Eustacia share a lot in common-both are vain, haughty, flirtatious, rebellious, intelligent and stubbornly courageous-but the narrator in Madding Crowd constantly reminds the reader how Bathsheba's impulsive nature brings about her suffering, while the narrator in Return constantly reminds the reader how Eustacia's passion and vitality might make her a greater being than she actually is. ${ }^{11}$

The difference in narrative strategy demonstrates a difference in genre: Madding Crowd is a melodrama and Return a hybrid of melodrama and tragedy. Michael Millgate frequently comments on the "melodramatic devices" in Madding Crowd and describes it as "melodramatic romanticism." ${ }^{12}$ Melodrama was a highly sentimental mode of representation popular in early and mid-Victorian era, and large quantities of poor quality theatre characterized by bad acting brought this genre a bad reputation. Nevertheless modern scholars have tried to broaden and rehabilitate it: Peter Brooks adopts the term to describe an aesthetic form and a mode of representation working both in the realm of theatre and the novel; ${ }^{13}$ Robert Heilman has rediscovered melodrama's psychological function in allowing the reader the pleasures of self-pity and the experience of wholeness brought by an identification with "monopathy," a "singleness of feeling."

In a melodrama chance and luck is frequently employed to dramatize and heighten the intense conflict between cosmic ethical forces, with the purpose of testifying to the existence of a moral universe. Brooks asserts that in a melodrama we find "a world where what one lives for and by is seen in terms of, and is determined by, the most fundamental psychic relations and cosmic ethical forces." 15 It highlights the stark ethical conflicts in human life: a protagonist fights against external forces and either wins or loses. If he wins he is awarded what his virtue deserves; 
if he loses he is battered by fate and chance. As in Madding Crowd, Oak is rewarded with Bathsheba and property for his moral righteousness and his loyalty to love.

This insight helps us to view Hardy's frequent use of coincidences, untimely chance and luck from a new perspective. Hardy was often accused by his contemporaries of violating the principles of verisimilitude, which he does not deny; but he justifies this strategy as being true to art: "Art is a disproportioning-(i.e., distorting, throwing out of proportion) — of realities, to show more clearly the features that matter in those realities, which, if merely copied or reported inventorially, might possibly be observed, but would more probably be overlooked."16 If we view this strategy as related to the technique of melodrama, we can discern how Hardy is pressing extreme conflicts, distorting realities to accentuate the essentials of life through "a bold reinvention of ethics." 17

Melodramatic elements are present in almost every Hardy novel and short story, and his narrators habitually conclude the narrative by alluding to chance and luck; yet what makes Return a hybrid of melodrama and tragedy is the narrator's ambiguous moral status and the absence of a moral universe. There is no cosmic moral order; moral luck no longer leads to poetic justice as it did in Madding Crowd. The reader finds the narrator as well as the characters struggling between different values and imperatives: the narrator admires human compassion and selfsacrifice, but cannot neglect that the so-called self-sacrifice unavoidably implicates cost to others; he cherishes human passion and spontaneity, but cannot ignore that such emotions essential for a flourishing life can be destructive and ruinous to life in a civilized world. He cannot help questioning the bases of our sense of superior moral integrity when we make moral judgments.

It seems clear that Hardy's shift of genre from melodrama to tragedy was conducted deliberately. On 18 February 1874 Hardy wrote to Leslie Stephen in reply to Stephen's suggestion for deletions to Madding Crowd: "The truth is that I am willing, and indeed anxious, to give up any points which may be desirable in a story when read as a whole, for the sake of others which shall please those who read it in numbers. Perhaps I may have higher aims some day, and be a great stickler for the proper artistic balance of the completed work, but for the present circumstances lead me to wish merely to be considered a good hand at a serial” ( $L W$, p. 102). This reveals how Hardy views Madding Crowd himself-an interesting pastoral story with no higher aims than serial 
publication. Return, however, is quite different: Michael Millgate confirms that when writing Return Hardy "had striven more deliberately than ever before to make the book an unmistakable work of art"; ${ }^{18} \mathrm{~T}$. R. Wright claims that Return is "probably Hardy's most ambitious book, the most difficult and demanding for readers"; ${ }^{19}$ while John Paterson provides convincing evidence to show that for this novel Hardy had in mind "a formal and structural analogy with Greek tragedy." ${ }^{20}$

Thus in Hardy's earlier novels moral luck tends to dramatize conflicts between different characters and forces and between virtue and vice. In Return and most of his later novels Hardy gradually turned to those key issues confronting a newly expanded industrialized and urbanized society. The life of the individual in the family, in courtship, and in marriage is related to larger historical, social, political, or spiritual themes; different dimensions of moral judgment also emerge as more and more distinctly conflicting. Moral luck becomes a problematic element which renders good will into dangerous results, or public prejudice into unfair persecution. This rough division, turning on Return, can help us understand why in his early novels moral luck often works for the worse of the "villains" or morally-flawed characters but rarely harms the integrity of the moral heroes, and why situations grow more intricate in later works and nobody can be exempt from moral bad luck.

With different aims in mind, Madding Crowd and Return provide the reader different aesthetic as well as ethical experiences. Madding Crowd encourages our belief in the existence of a moral universe and fosters our confidence in making the right moral judgment; while Return denies this belief and shows our moral deficiency and suggests human compassion and a hesitation of moral judgment as an urgent necessity for our moral existence. But should we thus conclude that Return is superior to Madding Crowd? I certainly reject this reduction.

First, Madding Crowd is an excellent melodrama while Return is an incomplete tragedy. Madding Crowd achieves a good balance in characterization, plotting and actions while the confusing characterization does make Return less successful-the two protagonists are overloaded by the heroic, mythical and tragic weight the narrator grants them. There seems to be a gap between what Hardy wants them to be and what they really are, since neither their words nor deeds can evoke the grandeur Hardy intends the reader to feel. The mythical and classical allusions and aestheticization hence seem to be incongruous, and the goal is yet to find a more satisfactory expression. 
Second, as Heilman argues, "Men not only write tragedy and melodrama but also, in quite nonliterary contexts, view human experience tragically or melodramatically." ${ }^{21}$ Both melodrama and tragedy are perspectives on life and both are indispensable for a firm grasp of human experiences and an accurate representation of what life feels like. Melodrama heightens our conflicts with external contingency and resolves these conflicts with extreme solutions so as to satisfy our wish to find model solutions to the problems in real life. Tragedy reminds us of the destructive agonies of inner dividedness and the antagonizing values and imperatives in human life. Melodrama gives us release, tragedy gives us catharsis.

Finally, the codes of moral judgment conveyed by melodrama and tragedy are both necessary for our moral practice. Melodrama encourages us to make moral judgments and identify with the virtuous characters, whereas tragedy tells us any moral judgment can be fallible and risky. This is exactly the relations we see between morality and ethics-ethics inquires how one should live, whereas morality asks what one should do. Tragedy warns of the danger of moral judgment and urges hesitation, whereas melodrama understands the necessity to make moral judgment and invites confidence. Confidence or hesitation-each manifests our outlook on life. Yet it is not a matter of "either/or" but a "both." Embracing both versions of experience will help us fathom the nature of moral luck and moral judgment, satisfy our need for an applicable moral existence and an ideal ethical existence, and reshape our ethical perspective and enrich our ethical experience.

UNIVERSITY OF HONG KoNG

1. Thomas Nagel, "Moral Luck," in Mortal Questions (Cambridge: Cambridge University Press, 1979), p. 26.

2. Martha Nussbaum, The Fragility of Goodness: Luck and Ethics in Greek Tragedy and Philosophy (Cambridge: Cambridge University Press, 1986), pp. 318-42.

3. Nafsika Athanassoulis, Morality, Moral Luck and Responsibility (New York: Palgrave Macmillan, 2005), pp. 106, 165.

4. Brian Rosebury, "Moral Responsibility and 'Moral luck," Philosophical Review 104 (1995): 499-524. See also Nafsika Athanassoulis, "Common-Sense Virtue Ethics and Moral 
Luck," Ethical Theory and Moral Practice 8 (2005): 265-76; Brynmor Browne, "A Solution to the Problem of Moral Luck," Philosophical Quarterly 42 (1992): 345-56; Henning Jensen, "Morality and Luck," Philosophy 59 (1984): 323-30; Nicholas Rescher, "Luck," Proceedings and Addresses of the American Philosophical Association 64 (1990): 5-19.

5. Rescher, p. 14.

6. Wayne Booth, The Company We Keep: An Ethics of Fiction (Berkeley: University of California Press, 1988), pp. 125-26.

7. Quotations of the two novels are taken from the Norton Critical Edition based on the Macmillan's 1912 Wessex Edition: Robert C. Schweik ed., Far From the Madding Crowd (New York: Norton, 1986); hereafter abbreviated Madding Crowd in the text and FMC in the note. James Gindin ed., The Return of the Native (New York: Norton, 1969); hereafter abbreviated Return in the text and $R N$ in the note.

8. Bernard Williams, "Moral Luck," in Moral Luck: Philosophical Papers, 1973-1980 (Cambridge: Cambridge University Press, 1981), p. 27.

9. Leonard W. Deen, "Heroism and Pathos in The Return of the Native," Nineteenth-Century Fiction 15 (1960): 207-19, p. 208.

10. Dale Kramer, Thomas Hardy: The Forms of Tragedy (Detroit: Wayne State University Press, 1975), p. 48.

11. See especially chap. 20 in $F M C$, chaps. 2 and 8 of Book First in $R N$.

12. Michael Millgate, Thomas Hardy: His Career as a Novelist (Basingstoke: Macmillan, 1994), pp. 86-87, 81 .

13. See Peter Brooks, The Melodramatic Imagination: Balzac, Henry James, Melodrama, and the Mode of Excess (New Haven: Yale University Press, 1976).

14. Robert B. Heilman, Tragedy and Melodrama: Versions of Experience (Seattle: University of Washington Press, 1968), p. 85.

15. Brooks, p. 13.

16. Thomas Hardy, The Life and Work of Thomas Hardy, ed. Michael Millgate (London: Macmillan, 1984), p. 239. Hereafter abbreviated $L W$.

17. Jil Larson, Ethics and Narrative in the English Novel, 1880-1914 (Cambridge: Cambridge University Press, 2001), p. 75.

18. Michael Millgate, Thomas Hardy: A Biography Revisited (Oxford: Oxford University Press, 2004), p. 184.

19. T. R. Wright, Hardy and His Readers (Basingstoke: Palgrave Macmillan, 2003), p. 104.

20. John Paterson, The Making of The Return of the Native, cited in RN, p. 350.

21. Heilman, p. 89. 